Cakrawala Dini: Jurnal Pendidikan Anak Usia Dini | p-ISSN 2087-1317 | e-ISSN 2621-8321 Vol. 12. No.I Mei 2021 | Hal 73-82

\title{
PEMEROLEHAN BENTUK BAHASA ANAK DI LINGKUNGAN KELUARGA TERDIDIK PERKOTAAN
}

\author{
Anita Dewi Kurniasari ${ }^{1}$, Yakub Nasucha ${ }^{2}$, Ali Imron Al-Ma'ruf ${ }^{3}$, Atiqa Sabardila ${ }^{4}$ \\ 1,2,3,4 Universitas Muhammadiyah Surakarta
}

\begin{abstract}
This study aims to describe the form of children's language acquisition in an urban educated environment. This study uses a qualitative approach with descriptive methods. Language acquisition is obtained through what is heard and practiced with the language and words they have. The subjects in this study were children aged three years in an educated environment in the city of Surakarta with a focus on the form of children's language. Methods of data collection in research using the observation method, recording technique, and note taking technique, the researcher only acts as an observer of the use of language obtained from informants. Furthermore, after obtaining some research data, the data was recorded on the data card according to the type of data. The results of the research on the form of language acquisition for children aged three years in an urban educated environment have language acquisition in the form of declarative, introgative, and imperative sentences. This sentence gets news sentences, explanations, information, and details to someone or the other person.

Keywords: Language acquisition, child characteristics, environment
\end{abstract}

\begin{abstract}
Abstrak: Penelitian bertujuan untuk memaparkan bentuk pemerolehan bahasa anak di lingkungan terdidik perkotaan. Penelitian ini menggunakan pedekatan kualitatif dengan metode deskriptif. Pemerolehan bahasa diperoleh melalui apa yang didengar dan dipraktikkan dengan bahasa dan kata yang mereka miliki. Subjek dalam penelitian ini anak usia tiga tahun di lingkungan terdidik di kota Surakarta dengan fokus bentuk bahasa anak. Metode pengumpulan data dalam penelitian menggunakan metode simak, teknik rekam, dan teknik catat, peneliti hanya berperan sebagai pengamat penggunaan bahasa yang diperoleh dari informan. Selanjutnya, setelah diperoleh sejumlah data penelitian, dilakukan pencatatan data pada kartu data sesuai dengan jenis data. Hasil penelitian bentuk pemerolehan bahasa anak usia tiga tahun di lingkungan terdidik perkotaan memiliki pemerolehan bahasa berupa kalimat deklaratif, introgatif, dan imperatif. Kalimat ini memperoleh kalimat berita, penjelasan, keterangan, serta perincian kepada seseorang atau lawan bicara.
\end{abstract}

Kata Kunci: Pemerolehan bahasa, karakteristik anak, lingkungan

\footnotetext{
'Universitas Muhammadiyah Surakarta, Email: anitadewik.ad国gmail.com

${ }^{2}$ Universitas Muhammadiyah Surakarta, Email: yakub.nasucha国ums.ac.id

${ }^{3}$ Universitas Muhammadiyah Surakarta, Email: ali.imran国ums.ac.id

${ }^{4}$ Universitas Muhammadiyah Surakarta, Email: as287国ums.ac.id
} 


\section{PENDAHULUAN}

Pemerolehan bahasa ialah faktor nurture dan faktor nature. Nature merupakan pemerolehan bahasa yang sudah ada sejak lahir sedangkan nurture merupakan pemerolehan bahasa yang dipengaruhi oleh lingkungan secara alami (Simanjuntak, 2017, hlm. 2). Pemerolehan bahasa pertama sangat penting bagi seorang anak karena akan menentukan penguasaan bahasa kedua dan bahasa selanjutnya (Suntini, dkk., 2018, hlm. 190) Selain itu, menurut Natsir (2017, hlm. 21) pemerolehan bahasa merupakan sebuah hal yang sangat menakjubkan terlebih dalam proses pemerolehan bahasa pertama yang dimiliki oleh seorang anak tanpa ada pembelajaran khusus mengenai bahasa tersebut kepada mereka. (Abdurrahman, dkk., 2019, hlm. 138) menjelaskan perkembangan bahasa anak merupakan kemampuan anak untuk memberikan respon terhadap suara, mengikuti perintah, dan berbicara sopan. Perkembangan bahasa pada anak usia dini sangat penting karena dengan bahasa sebagai dasar kemampuan seorang anak akan dapat meningkatkan kemampuankemampuan yang lain (Gani, 2017, hlm. 151).

Bahasa adalah salah satu alat terpenting dalam kehidupan setiap orang. Setiap mereka tentu saja tidak terlepas dari bahasa. Hal tersebut sesuai dengan yang dinyatakan (Maharany, 2016, hlm. 2) Dalam kehidupan sehari-hari, bahasa termasuk alat yang sangat penting digunakan manusia untuk berkomunikasi. (Nur, 2017, hlm. 202) menjelaskan bahasa merupakan alat komunikasi verbal antara individu dalam kegiatan bersosialisasi. Dengan adanya bahasa, penutur mampu mengungkapkan keinginan, harapan, serta permintaan kepada mitra tuturnya.

Selain itu, Ismail (2016, hlm. 411) juga berpendapat bahwa bahasa digunakan sebagai alat penyampaian pesan dari diri seseorang kepada orang lain, atau dari pembaca kepada pendengar, dan dari penulis ke pembaca manusia berinteraksi menyampaikan informasi kepada sesamanya. Selain itu, orang dapat mengemukakan ide-idenya, baik secara lisan maupun secara tulis/gambar. Dalam kehidupan sehari-hari manusia menggunakan bahasa untuk berbagai kegiatan (Ekawati, 2017, hlm. 2) Jadi, bahasa memiliki peran penting untuk kegiatan berkomunikasi sehingga dengan bahasa tersebut manusia dapat saling bertukar informasi.

Hal tersebut sesuai dengan yang dinyatakan Saputri (2018, hlm. 210) bahwa pemerolehan bahasa anak atau yang biasa disebut akuisisi bahasa menunjukkan adanya potensi yang dapat diukur dalam otak manusia, khususnya anak-anak.

Anak usia dini memiliki karakteristik yang berbeda dengan orang dewasa karena anak usia dini tumbuh dan berkembang dengan banyak cara dan berbeda (Nuraeni, 2015, hlm. 17). Jadi, anak usia dini mempunyai kemampuan lebih peka menyerap sesuatu serta memiliki ingatan yang cenderung lebih cepat dibandingkan dengan usia-usia diatas balita. Hal tersebut sesuai dengan yang dinyatakan (Sumaryanti, 2017, hlm. 73) bahwa anak dapat mengekspresikan dan mengaktualisasikan apa yang ada dalam pikirannya melalui bahasa dengan tujuan agar orang lain dapat memahami apa yang dipikirkan oleh anak tersebut. Pada masa ini terjadilah proses pertumbuhan dan perkembangan dalam berbagai aspek, salah satu diantaranya adalah aspek dalam interaksi sosial (Khotimah, dkk., 2016, hlm. 1). Selain itu, menurut (Fitriani, 2018, hlm. 14) Pembentukan karakter anak tidaklah lahir begitu saja, ada proses yang dilewatinya sehingga proses tersebut pun menjadi karakter yang melekat dalam diri seorang anak. Mulai dari anak tersebut lahir dan tumbuh berkembang menjadi dewasa di lingkungan keluarga, bergaul dengan teman-teman dalam kelompok permainan, sekolah, sampai dengan masyarakat. Sebagai orang tua, tanpa disadari, sikap 
orang tua yang negatif pada anaknya pun justru akan menjatuhkan anak tersebut.

Masa anak usia dini merupakan masa keemasan atau sering disebut dengan golden age period karena pertumbuhan dan perkembangan berlangsung sangat singkat dan peka terhadap lingkungan (Parsia, dkk., 2017, hlm. 972). Lingkungan sosial sangatlah berpengaruh dalam perkembangan bahasa anak. Di era globalisasi, anak semakin mudah untuk menangkap apa yang telah mereka dapat terlebih pada lingkungan perkotaan peran orang tua dan keluarga menjadi salah satu faktor pendukung perkembangan anak tersebut. Hal ini sesuai dengan yang diungkapkan (Syarif, dkk., 2017, hlm. 98) Lingkungan keluarga terutama keluarga inti adalah lingkungan pendidikan pertama dan paling utama. Lingkungan keluarga merupakan ajang di mana sifat-sifat keperibadian anak terbentuk, jadi keluarga adalah sebagai pendidikan pertama bagi anak (Setiawan dkk., 2017, hlm. 113).

Hasil penelitian Wulandari (2018) menemukan pemerolehan afkisasi dari segi fonologi, morfologi, sintkasis, dan semantik. Sobari, dkk. (2018) meneliti pemerolehan bahasa yang dikaji dengan ilmu fonologi, objek tersebut memiliki beberapa proses yaitu proses distribusi struktur suku kata dan proses asimilasi. Crowe, dkk. (2018) meneliti penguasaan bicara anak yang melibatkan presepsi dan produksi konsonan, vocal, kelompok konsonan, nada, ciri prosidi, dan aturan fonologis bahasa yang mereka pakai dengan hasil dari pidato yang dimengerti. Penelitian Barner (2013) menunjukan bahwa anak-anak pertama-tama mempelajari kata-kata waktu sebagai kelas leksikal, kemudian mempelajari hubungan ordinal mereka, tetapi pada awalnya hanya memiliki sedikit pengetahuan tentang durasi relative mereka. Pemahaman ini muncul terlambat setelah anak mulai menggunakan kata waktu dalam berbicara.
Hasil penelitian Sudarsana (2017) menemukan kurangnya kesadaran masyarakat akan pentingnya pendidikan pada usia dini, masih terbatas dan tidak merata, lembaga layanan paud yang ada di masyarakat, rendahnya dukungan pemerintah dalam penyelenggaraan pendidikan anak usia dini. Penelitian Permono (2013) menemukan pendidikan karakter bukan sekedar mengajarkan mana yang benar dan mana yang salah, lebih dari itu, pendidikan karakter menanamkan kebiasaan (habituation) tentang hal mana yang baik sehingga anak-anak menjadi paham (kognitif) tentang mana yang benar dan salah, mampu merasakan (afektif) nilai yang baik dan biasa melakukannya (psikomotor). Sumaryanti (2017) menemukan faktor-faktor yang dapat mempengaruhi perkembangan bahasa anak: perekembangan otak dan kecerdasan, jenis kelamin, kondisi fisik, lingkungan keluarga, kondisi ekonomi, setting social/lingkungan budaya, bilingualism (dua bahasa). Penelitian Zou (2016) menemukan karakteristik penguasaan bahasa ibu (anak-anak) berbeda dengan penguasaan bahasa kedua (orang dewasa), dan prosesnya sangat berbeda. Penguasaan bahasa ibu (anakanak) dapat memiliki efek besar pada perubahan penguasaan bahasa kedua orang dewasa.

Hasil penelitian Setiawan, dkk. (2017) menemukan variabel minat belajar internal anak sebesar $61 \%$ dipengaruhi oleh variabel lingkungan keluarga. Sisanya sebesar $39 \%$ di pengaruhi oleh faktor-faktor lain, seperti faktor internal meliputi faktor jasmaniah dan faktor pskiologi. Faktor eksternal meliputi faktor keluarga, faktor sekolah dan faktor masyarakat. Penelitian Syarif, dkk. (2017) menemukan jenis presepsi siswa terhadap pola asuh orang tua, presepsi siswa terhadap pola asuh orangtua memiliki pengaruh langsung dan signifikan terhadap hasil belajar siswa. Tingkat pendidikan orang tua memiliki pengaruh 
langsung dan signifikan terhadap hasil belajar siswa. Penelitian Ariculi (2016) meneliti tentang perbedan individu dalam pembelajaran (SL), yang telah terlibat dalam penguasaan bahasa, secara independent memprediksi pemahaman sintaksis yang berusia 6-8 tahun. Penelitian Vohr (2019) meneliti tentang percakapan anak usia 18 dan 24 bulan yang memiliki korelasi dengan bahasa dan memiliki kemampuan kognitif. Temuan Vohr menggarisbawahi perlunya program intervensi dini yang efektif yang mendukung orang tua dalam menciptakan suatu lingkungan belajar bahasa yang optimal di rumah. Apakah benar pemerolehan bahasa mimiliki bentuk pemerolehan bahasa? Penelitian ini akan menjawab pertanyaan tersebut.

Pada penelitian sebelumnya, pembahasan mengenai pemerolehan bahasa pada umumnya mendeskripsikan tentang kajian fonologi, semantik, morfologi, dan sintaksis. Adapun dalam penelitian ini membahas pemerolehan bahasa anak berdasarkan bentuk kalimat, mencakup: kalimat deklaratif, interogatif, dan kalimat imperatif.

Alasan dipilihnya anak usia 3 tahun khususnya di lingkungan terdidik perkotaan, berdasarkan pengamatan, karena pada usia tersebut anak mulai menunjukkan gambaran dan karakter kepribadiannya sehingga pada usia tersebut anak memiliki kemampuan untuk mengutarakan apa yang mereka terima sehingga dapat memudahkan peneliti untuk mendapatkan data. Hal ini sesuai dengan yang dinyatakan (Khairi, 2018, hlm. 16) Anak usia dini merupakan individu yang berbeda, unik, dan memiliki karakteristik tersendiri sesuai dengan tahapan usianya.

\section{METODOLOGI PENELITIAN}

Metode penelitian ini menggunakan metode simak, teknik rekam, dan teknik catat. Metode simak dilakukan dengan cara mendengarkan hasil rekaman percakapan antara anak dengan ibunya dan lingkungan sekitarnya. Teknik rekam digunakan untuk memperoleh data berupa suara yang bersumber dari rekaman percakapan informan. Selanjutnya, setelah diperoleh sejumlah data penelitian, dilakukan pencatatan data pada kartu data sesuai dengan jenis data.

Analisis data penelitian ini menggunakan metode padan referensial. Metode tersebut digunakan untuk mengumpulkan data berupa kata dan kalimat kemudian data tersebut diklasifikasikan menurut bentuk bahasa anak usia tiga tahun dilingkungan terdidik perkotaan.

Selain itu, digunakan metode agih dengan sejumlah tekniknya, yakni teknik perluas, delesi, gabung, ganti, sisip, dan teknik parafrase. Teknik ini digunakan terakhir kali setelah melakukan analisis, dengan menggunakan teknik tersebut dapat diketahui garis besar hasil dari penelitian ini. Validasi data menggunakan triangulasi sumber data. Teknik penyajian data dilakukan dengan penyajian informal.

\section{HASIL PENELITIAN DAN PEMBAHASAN}

Bentuk bahasa yang diperoleh anak usia tiga tahun di lingkungan terdidik perkotaan dalam penelitian ini meliputi, kalimat deklaratif, kalimat interogatif, dan kalimat imperative (Chaer, 2015, hlm. 238). Bentuk bahasa yang di ujarkan anak usia tiga tahun berkaitan dengan lingkungan sekolah, lingkungan keluarga dan di lingkungan rumah. Hasil pemerolehan bentuk bahsa tersebut, disajikan dalam table sebagai berikut. 
1.Tabel : Bentuk Kalimat Deklaratif

\begin{tabular}{|c|c|c|c|c|}
\hline No. & $\begin{array}{c}\text { Identitas } \\
\text { Anak }\end{array}$ & $\begin{array}{c}\text { Kalimat } \\
\text { Deklaratif }\end{array}$ & Arti & $\begin{array}{c}\text { Variasi } \\
\text { Kalimat }\end{array}$ \\
\hline 1. & Ey & $\begin{array}{l}\text { Ambar } \\
\text { antu aku } \\
\text { tadi }\end{array}$ & $\begin{array}{l}\text { Menggambar } \\
\text { hantu aku } \\
\text { tadi }\end{array}$ & $\begin{array}{l}\text { P-S- } \\
\text { Keterangan } \\
\text { waktu }\end{array}$ \\
\hline 2. & $\mathrm{Ar}$ & $\begin{array}{l}\text { Ini } \\
\text { uthamen } \\
\text { chantik }\end{array}$ & $\begin{array}{l}\text { Ini ultramen } \\
\text { cantik }\end{array}$ & S-P \\
\hline 3. & $\mathrm{Ra}$ & $\begin{array}{l}\text { Aku elum } \\
\text { andhi } \\
\text { nggu } \\
\text { amah } \\
\text { ulang }\end{array}$ & $\begin{array}{l}\text { Aku belum } \\
\text { mandi, } \\
\text { menunggu } \\
\text { mama } \\
\text { pulang }\end{array}$ & $\begin{array}{l}\text { S-P- } \\
\text { Keterangan } \\
\text { sebab }\end{array}$ \\
\hline 4. & $\mathrm{Sa}$ & $\begin{array}{l}\text { Iya tadi } \\
\text { itu ada } \\
\text { ailnya }\end{array}$ & $\begin{array}{ll}\text { Iya, } & \text { tadi } \\
\text { disiitu } & \text { ada } \\
\text { airnya } & \\
\end{array}$ & K-P-O \\
\hline 5. & $\mathrm{Ki}$ & $\begin{array}{l}\text { Aku mau } \\
\text { buah } \\
\text { jeluk satu } \\
\text { yah }\end{array}$ & $\begin{array}{l}\text { Aku mau } \\
\text { buah jeruk, } \\
\text { satu ya }\end{array}$ & S-P-O \\
\hline
\end{tabular}

2. Tabel : Bentuk Kalimat Introgatif

\begin{tabular}{lllll}
\hline No. & $\begin{array}{c}\text { Identitas } \\
\text { Anak }\end{array}$ & $\begin{array}{l}\text { Kalimat } \\
\text { Imperatif }\end{array}$ & \multicolumn{1}{c}{ Arti } & $\begin{array}{l}\text { Variasi } \\
\text { Kalimat }\end{array}$ \\
\hline 6. & Ft & $\begin{array}{l}\text { Esok beli } \\
\text { uku } \\
\text { mewanai } \\
\text { ma? }\end{array}$ & $\begin{array}{l}\text { Besok } \\
\text { membeli } \\
\text { buku } \\
\text { mewarnai } \\
\text { ma? }\end{array}$ & K-P-O \\
\hline 7. & Ze & $\begin{array}{l}\text { Kalau uaya } \\
\text { makannya } \\
\text { apa? }\end{array}$ & $\begin{array}{l}\text { Kalau } \\
\text { buaya } \\
\text { makannya } \\
\text { apa? }\end{array}$ & S-P \\
& & & & \\
\hline & & & &
\end{tabular}

3. Tabel : Kalimat Imperatif

\begin{tabular}{lllll}
\hline No. & $\begin{array}{c}\text { Identitas } \\
\text { Anak }\end{array}$ & $\begin{array}{c}\text { Kalimat } \\
\text { Interogatif }\end{array}$ & Arti & $\begin{array}{c}\text { Variasi } \\
\text { Kalimat }\end{array}$ \\
\hline 8. & Di & $\begin{array}{l}\text { Embalikan } \\
\text { keitu }\end{array}$ & $\begin{array}{l}\text { Kembalikan } \\
\text { kesitu }\end{array}$ & P-K \\
\hline
\end{tabular}

Pemorolehan bentuk bahasa anak meliputi: Kalimat deklaratif, interogatif, dan imperative, (Chaer, 2015, hlm. 238). Bentuk bahasa ini berkaitan dengan lingkungan sekolah, keluarga, dan lingkungan rumah. Berikut analisis bentuk bahasa anak usia tiga tahun di lingkungan terididik perkotaan.

\section{Kalimat Deklaratif}

Kalimat deklaratif pada artikel ini digunakan anak untuk menyampaikan sebuah berita atau informasi. Hal ini sesuai dengan yang disampaikan Gani dan Mustika (2019, hlm. 195) bahwa kalimat deklaratif berisi sebuah penyampaian pernyataan atau informasi ditunjukkan kepada orang lain. Berdasarkan data yang ditemukan, ujaran yang disampaikan lebih cenderung mengungkapkan kalimat deklaratif. Hal ini terlihat dari jumlah kalimat deklaratif yang ditemukan.

a. Kalimat deklaratif berfungsi untuk menyampaikan berita secara faktual

(1) Ujaran : Ambar antu aku tadi Arti : Menggambar hantu aku tadi

Pengujar : Ey kepada Us

Data (1) kalimat deklaratif pada data (1) digunakan pengujar untuk menyampaikan sebuah informasi secara faktual berdasarkan apa yang sedang terjadi, hal ini sejalan dengan yang disampaikan Usman Hakim (2015, hlm. 23) kalimat deklaratif digunakan untuk menyampaikan informasi berkenaan dengan pengalaman penutur, hal ini ditunjukkan pada ujaran "ambar antu aku tadi" informasi ini bersifat faktual disampaikan kepada us setelah ey melakukan kegiatan tersebut. Sturuktur ujaran yang disampaikan berpola kalimat yang menonjolkan aktifitas yang dilakukan yaitu "menggambar" sebagai (P) pelakunya adalah " $a k u$ " (S) tadi sebagai (Keterangan waktu), pola kalimat yang terbentuk menunjukkan sebuah bentuk kalimat deklaratif yang diujarkan ey untuk menyampaikan sebuah informasi berdasarkan apa yang sudah dilakukan. Ujaran yang dilakukan ey berlangsung pada pagi hari di ruang kelas.

b. Kalimat deklaratif memberi penjelasan, keterangan, serta perincian kepada seseorang 
(2) Ujaran : Ini uthamen chantik Arti : Ini ultramen cantik

Pengujar : Ar kepada Ti

Data (2) kalimat deklaratif pada data (2) memiliki bentuk kalimat memberikan penjelasan serta perincian kepada seseorang. Hal ini sejalan dengan yang disampaikan Reva, dkk (2019, hlm. 22) bahwa kalimat deklaratif merupakan pernyataan untuk menyampaikan suatu peristiwa tanpa mengharapkan respon dari lawan bicara. Struktur kalimat yang diujarkan anak memiliki pola kalimat penekanan pada subjek dan predikat, kata "ini" merupakan kata tunjuk yang berfungsi sebagai penegas bahwa "ultramen itu cantik" yang menunjukkan suatu benda. Struktur kalimat yang diujarkan digunakan pengujar untuk menyampaikan sebuah berita berupa penjelasan dan perincian kepada $\mathrm{Ti}$, ujaran berlangsung di ruang tamu pada sore hari ketika sedang bermain.

$\begin{array}{ll}\text { (3) Ujaran } & \text { Aku elum andhi } \\ & \text { nggu amah ulang } \\ \text { Arti } & : \begin{array}{l}\text { Aku belum mandi } \\ \text { menunggu mama } \\ \end{array} \\ \text { pulang } \\ \text { Pengujar }: \text { Ra kepada Di }\end{array}$

Data (3) bentuk kalimat deklaratif pada data (3) digunakan pengujar untuk memberikan sebuah berita berupa penjelasan keterangan. Hal ini sejalan dengan Siti, dkk (2019, hlm. 11) bahwa kalimat deklaratif merupakan kalimat pernyataan untuk memberitahukan sesuatu. Struktut kalimat yang di ujarkan menjelaskan tentang situasi yang dialami. "Aku" sebagai (subjek) "belum mandi" sebagai (predikat) "menunggu mama pulang" (keterangan sebab). Ujaran yang disampaikan $\mathrm{Ra}$ kepada Di digunakan untuk menyampaikan sebuah penjelasan, bahwa Ra akan mandi ketika mama sudah pulang kerja. Ujaran berlangsung diruang tamu pada sore hari.
(4)

$\begin{array}{ll}\text { Ujaran } & : \begin{array}{l}\text { iya , tadi itu ada } \\ \text { ailnya }\end{array} \\ \text { Arti } & : \begin{array}{l}\text { Iya, tadi itu ada } \\ \text { airnya }\end{array} \\ \text { Pengujar } \quad: \text { Sa kepada Us }\end{array}$

Data (4) merupakan bentuk kalimat deklaratif untuk menginformasikan sebuah berita dengan memberikan sebuah penjelasan. Hal ini sesuai dengan yang dinyatakan Sari dan Siregar (2016, hlm. 12) bahwa kalimat deklaratif umumnya digunakan pembicara untuk menyampaikan berita atau penjelasan. Struktur kalimat yang diujarkan merupakan penegasan jawaban "Itu tadi" sebagai kata tunjuk yang menunjukkan tempat yang ditanyakan. "Ada airnya" sebagai predikat. Struktur tersebut digunakan pengujar untuk memberitahukan sebuah berita bahwa di tempat bermain ada airnya, sehingga $\mathrm{Sa}$ harus memindahkan prosotannya ketempat lain. Ujaran berlangsung di halaman bermain pada waktu istirahat.

$\begin{array}{lll}\text { Ujaran } & : \text { Aku uah jeluk } \\ & \text { satu } \\ \text { Arti } & : \text { Aku buah jeruk } \\ & \text { satu } \\ \text { Pengujar } & \text { : } & \text { Ki kepada Wi }\end{array}$

Data (5) kalimat deklaratif pada data (5) memiliki bentuk kalimat yang digunakan untuk menyampaikan informasi berupa penjelasan dan perincian kepada oranglain. Hal ini sesuai dengan yang dinyatakan Anggreni dan Made (2019, hlm. 89) bahwa kalimat deklaratif berisi tentang suatu hal, suatu hal tersebut merupakan kalimat berita. Kalimat berita yang diujarkan pengujar memiliki pola kalimat " $A k u$ " (subjek) "mau" (predikat) "buah jeruk satu" (o). Kalimat ini digunakan $\mathrm{Ki}$ untuk menyampaikan sebuah berita kepada Wi bahwa ia ingin memesan buah jeruk satu. Ujaran ini berlangsung ketika sedang beramain bersama teman, pada pagi hari. 


\section{Kalimat Interogatif}

Kalimat introgatif pada artikel ini memiliki bentuk kalimat tanya yang membutuhkan jawaban "ya" atau tidak" serta bentuk kalimat yang diperoleh dengan bantuan kata tanya. Hal ini sesuai dengan yang disampaikan Haryadi, dkk (2017, hlm. 22) bahwa kalimat introgatif dapat diwujudkan dengan menggunakan kata apa atau apakah yang kemudian membutuhkan jawaban "ya" atau "tidak". Berdasarkan data yang ditemukan, kalimat interogatif ini termasuk kalimat kedua yang sering diucapkan oleh subjek penelitian. Hal ini terlihat dari jumlah kalimat interogatif yang ditemukan.

a. Kalimat jawaban "ya" atau "tidak" berupa keterangan waktu

$\begin{array}{lll}\text { Ujaran } & : \text { Esok beli uku } \\ & \text { mewanai ma? } \\ \text { Arti } & : \text { Besok membeli } \\ & \text { buku mewarnai } \\ & \text { ma? } \\ \text { Pengujar } \quad: & \text { Ft kepada Ma }\end{array}$

Data (6) merupakan bentuk kalimat yang diujarkan subjek peneliti yang berupa kalimat interogatif, kalimat yang diujarkan membutuhkan jawaban "ya" atau tidak", sesuai dengan yang disampaikan Lindawati (2015, hlm. 5) Kalimat introgatif, kalimat yang berisi mengenai pertanyaan dengan lagu tanya, ditunjukan pada ujaran yang disampaikan Ft kepada Ma subjek yang dituturkan anak pada kalimat ini dilesapkan disampaikan dengan kalimat "Esok beli uku mewanai $m a$ " yang digunakan pengujar untuk meminta jawaban keterangan waktu. Kalimat ini menonjolkan pada penekanan waktu, berlangsung sore hari.

b. Bantuan kata tanya

$\begin{array}{ll}\text { (7) Ujaran } & : \text { Kalau uaya } \\ & \text { makannya apa? } \\ \text { Arti } & : \text { Kalau buaya } \\ & \text { makan apa? } \\ \text { Pengujar } \quad: \text { Ze kepada Us }\end{array}$

Data (7) bentuk kalimat introgatif dengan bantuan kata tanya, hal ini sejalan dengan yang disampaikan Nirmala dan Marissa (2020, hlm. 32) bahwa kalimat introgatif digunakan untuk menanyakan sesuatu. Kata "Kalau” hanya sebagai kata sambung yang tidak menduduki fungsi kalimat. Kalimat ini diujarkan kepada Ze untuk meminta jawaban kepada $\mathrm{Uz}$, ujarang berlangsung pagi hari diruang kelas.

\section{Kalimat imperative}

Rizka dan Chairul (2016, hlm. 13) menyampaikan bahwa kalimat perintah atau suruhan dapat diperinci menjadi beberapa bentuk kalimat perintah. Dalam penelitian ini, ditemukan kalimat imperatif berupa larangan. Kalimat ini termasuk kalimat yang jarang diucapkan oleh subjek peneliti. Hal ini terlihat dari jumlah kalimat deklaratif yang ditemukan.

a. kalimat perintah larangan

Data (8) bentuk kalimat imperative yang diujarkan memiliki kalimat perintah larangan. Hal ini sejalan dengan yang disampaikan Ahmad (2019, hlm. 42) bahwa kalimat imperatif merupakan kalimat yang mengharapkan tanggapan yang berupa tindakan dari orang yang diajak bicara dan ditandai dengan intonasi suruh. Struktur kalimat yang diujarkan memiliki pola kalimat "Kembalikan" (predikat) "kesitu” (keterangan), pola kalimat ini diujarkan Di untuk memerintah Sa untuk mengembalikan prosotonnya ketempat semula, dan melarang Sa untuk tidak bermain dahulu sebelum prosotannya dipindahkan. Ujaran berlangsung dihalaman bermain pada jam istirahat. 


\section{KESIMPULAN}

Bentuk pemerolehan bahasa anak usia tiga tahun di lingkungan terdidik perkotaan yang berupa kalimat deklaratif berfungsi untuk menyampaikan berita secara faktual. Kalimat yang diungkapkan berupa penjelasan, keterangan, serta perincian kepada seseorang atau lawan bicara. Ditinjau dari segi struktur, kalimat yang diungkapkan berpola: /P-SKet.Waktu/; /S-P/; /S-P-Ket.Sebab/; /K-P$\mathrm{O} /$; /S-P-O/. Pola kalimat tersebut sangat bervariasi, dan ada fungsi yang dilesapkan, Jadi, kalimat yang diungkapkan tidak menunjukkan pola kalimat normal.

Perolehan bahasa yang berupa kalimat introgatif memiliki bentuk kalimat tanya yang membutuhkan jawaban singkat. Kalimat tersebut diwujudkan dengan menggunakan kata apa atau apakah yang kemudian membutuhkan jawaban "ya" atau "tidak". Namun, ditemukan pula kalimat introgatif yang secara eksplisit kata tanya "apa" tidak diungkapkan. Pengujar langsung bertanya sesuatu yang diamaksudkan tanpa menggunakan kata "apa".

Perolehan bahasa yang berupa kalimat imperatif diungkapkan oleh pengujar berupa kalimat perintah atau suruhan. Variasi kalimatnya berupa kalimat perintah berbentuk larangan.

\section{DAFTAR PUSTAKA}

Abdurrahman, dkk. (2019) Pemerolehan Bahasa pada Anak Usia 3 Tahun. Jurnal Pendidikan Anak Usia Dini, 3(1). 137-145.

Ahmad, J. (2019). Modus Kalimat Perintah Larangan dalam "Asbab Wurud Al-Hadist" Karya Imam Suyuthi Kajian Pragmatik. Jurnal CMES, 12(1). 38-51.

Anggreni dan Made. (2019). Pola Kesantunan Kalimat Permintaan pada Model Dialog English for Waiter pada Mahasiswa Stipar Triatma Jaya. Jurnal Manajemen, 3(2). 86-94.
Ariculi, J. \& Evan, K. (2016). Individual

Differences in Statistical Learning Predict Children's Comprehension of Syntax. Child Development. 1(87). 184-193.

Barner, D. \& Katharine, A. T. (2013). Learning the language of time: Children's acquisition of duration words. Proceedings of the Annual Meeting of the Cognitive Science Society. 35(35). 57-77.

Chaer, A. (2015). Psikolinguistik: Kajian Teoritik. Bandung: Rineka Cipta

Crowe, dkk. (2018). Children's Consonant Acquisition in 27 Languages: A Cross-Linguistic Review. American Journal of Speech-Language Pathology. 126.

Ekawati, M. (2017). Kesantunan Simu pada Tindak Tutur Ekspresif Marah dalam Bahasa Indonesia. Jurnal Bahasa dan Sastra, 1(1). 1-22.

Gani, dkk. (2019) Memahami Bahasa Anak Usia 14 Bulan Melalui Unsur "Non-Linguistik". Jurnal Obsesi, 3(1). 146-152.

Haryadi, dkk. (2017). Kesantunan Berbahasa dalam Wacana Rubrik "Ngresula" Radar Tegal. Jurnal Sastra Indonesia, 6(2). 12-24.

Ismail. J. (2016). Tindak Tutur Dalam Film "Surat Kecil Untuk Tuhan" Karya Harris Nizam: Sebuah TInjauan Pragmatik dan Implikasinya terhadap Pembelajaran Bahasa. Jurnal Pendidikan, 14(1). 411-422.

Khairi, H. (2018). Karakteristik Perkembangan Anak. Jurnal Warna, 2(2). 15-28.

Khotimah, dkk. (2016). Dampak Penggunaan Gadget Terhadap Interksi Sosial Anak Usia 5-6 Tahun. 5(3) 182-186.

Lindawati. (2015). Kalimat Imperatif Bahasa Kepulauan Tukang Besi. Jurnal Humanika, 15(3). 1-17. 
Maharany, F.A. (2016). Gejala Fonologis

Bahasa Indonesia pada Anak Usia 3-4 Tahun di Paud Pertama Hati Kota Kendari. Jurnal BastraI, (1)2. 1-21.

Natsir, N. (2017). Hubungan Psikolinguistik dalam Pemerolehan dan Pembelajaran Bahasa. Jurnal Retorika, 10(1). 171.

Nur, Y. (2017). Karakteristik Bahasa Anak di Masyarakat Multietnik pada Pendidikan Anak Usia Dini di Kota Palu. Asia Journal of Environment, (1)1. 201-209.

Nuraeni, L. (2015). Pemerolehan Morfologi (Verba) pada Anak Usia 3,4 dan 5 Tahun (Suatu Kajian Neuro Psikolinguistik). Tunas Siliwangi. 1(1). 13-30.

Permono, H. (2013). Peran Orangtua dalam Optimalisasi Tumbuh Kembang Anak untuk Membangun Karakter Anak Usia Dini. Prosiding Seminar Nasional Parenting. 34-47.

Reva, dkk. (2019). Kesantunan Deklaratif: Kajian

Sosiopragmatik Kasus di Kecamatan Luas Kabupaten Kaur. Jurnal KIBASP. 3(1). 1731.

Saputri, R. (2018). Pemerolehan Bahasa Anak Usia 3 Tahun. Jurnalis Trendi, 2(4). 210-214.

Sari dan Siregar. (2016). Pemerolehan Bahasa Anak Usia 7 Tahun 3 Bulan dalam Bidang Sintaksis. Jurnal Edukasi Kultura, 1(2). 818.

Setiawan, dkk. (2017). Pengaruh Lingkungan Keluarga terhadap Minat Belajar Siswa. Jurnal Paedagogie. 5(2). 111-119.

Simanjuntak, M. (2017). Pemerolehan Bahasa Anak (Kajian Mean of Utterence 'Mlu') Fortunata Roito Situmorang (Anak Usia Satu Sebelas Bulan). Jurnal Bahasa, 111.
Siti, dkk. (2019). Penggunaan Kalimat Berdasarkan Makna dalam Kegiatan Diskusi Pembelajaran Bahasa Indonesia Siswa Kelas VII. Jurnal Kata, 2(1). 1-11.

Sobari, dkk. (2018). Pemerolehan Bahasa Anak usia 2-3 Tahun ditinjau dari Aspek Fonologi. Jurnal Pendidikan Bahasa dan Sastra Indonesia. 4(1). 591-602.

Sudarsana, K. I. O. (2017). Membentuk Karakter Anak Sebagai Generasi Penerus Bangsa Melalui Pendidikan Anak Usia Dini. Purwadita: Jurnal Agama dan Budaya. 1(1). 41-48.

Sumaryanti, L. (2017). Peran Lingkungan terhadap Perkembangan Bahasa Anak. MUDDIB. 7(1). 72-89.

Suntini, dkk. (2018). Analisis Pemerolehan Bahasa pertama pada Anak Usia Satu Tahun Sampai Usia Lima Tahun di Kelurahan. Jurnal Pendidikan Bahasa dan Sastra Indonesia, 13(2). 190-198.

Syarif, dkk. (2017). Pengaruh Presepsi Siswa Terhadap Pola Asuh Orangtua Dan Tingkat Pendidikan Orangtua Terhadap Motivasi Dan Hasil Belajar Biologi Siswa Kelas X Dan XI Ipa SMAN 8 Makasar Tahun Ajaran 2017/2018. Prosiding Seminar Nasional. 4(1). 98-464.

Usman, H. (2015). Studi Pemerolehan Bahasa pada Anak Usia 4 Tahun (Kajian Sintaksis). Jurnal Linguistik Terapan. 5(2). 16-27.

Vohr, dkk. (2019). Language Experience in the Second Year of Life and Language Outcomes in Late Childhood. Pediatrics. 4(142). 311.

Wulandari, I. D. (2018). Pemerolehan Bahasa Indonesia Anak Usia 3-5 Tahun di PAUD Lestari Desa Blimbing Kecamatab Pacitan Kabupaten Lamongan. Jurnal Bahasa. 6(1). 74-83. 
Zou, Q. \& Fei, D. (2016). A Study on Whether the Adults' Second Language Acquisition Is Easy or Not-From the Perspective of Children's Native Language Acquisition. Academi Publication. 694). 776-780. 